\title{
The Dynamics of Indonesia - Japan Economic and Financial Relations: A Review of the 60 Years Collaboration
}

\author{
Eko NM Saputro \\ Ministry of Finance, Indonesia
}

\begin{abstract}
Economic and financial ties between Indonesia and Japan have flourished in the recent decade covering many areas of cooperation. The cooperation between the two is interesting to explore since it involves economic interests and other aspects such as politics and social dynamics. From Indonesia point of view, this study attempts to shed light on recent economic-financial cooperation between Indonesia and Japan, particularly on overseas development assistance, financial supports, investment, and trade relations. It is found that while, in general, economic and financial cooperation between Indonesia and Japan has been relatively robust, there are some issues related to investment and trade that need to be addressed.
\end{abstract}

Keywords: Indonesia-Japan relations, overseas development assistance, financial cooperation, bilateral trade, investment

Perkembangan hubungan ekonomi dan keuangan antara Indonesia dan Jepang telah berkembang di berbagai bidang dalam satu dekade terakhir. Lebih dari itu, kerja sama keduanya selalu menarik untuk dipahami mengingat tidak hanya melibatkan kepentingan ekonomi semata, namun juga aspek lain seperti pertimbangan politik dan sosial. Tulisan ini akan mencoba menjelaskan kerja sama ekonomi dan keuangan antara Indonesia dan Jepang. Berfokus pada sudut pandang Indonesia, analisis dalam tulisan ini menjelaskan mengenai bantuan pembangunan luar negeri, dukungan keuangan, investasi, dan hubungan perdagangan. Studi ini menemukan bahwa meskipun secara umum kerja sama ekonomi dan keuangan antara Indonesia dan Jepang telah relatif kuat, terdapat beberapa masalah terkait dengan investasi dan perdagangan, yang perlu ditangani.

Kata-kata kunci: Hubungan Indonesia-Jepang, bantuan luar negeri untuk pembangunan, kerja sama keuangan, perdagangan bilateral, investasi 
The Dynamics of Indonesia - Japan Economic and Financial Relations: A Review of the 60 Years Collaboration

\section{Background of Indonesia and Japan Relationship}

Asia has been in dynamic changes ever since the end of World War II. The post-World War II period observed the tide of decolonization in the region. Despite the nomenclature of the "Cold War" to express the period from the end of World War II till around 1990, several hot wars occurred in Asia - from the Korean War and the Vietnam War as proxy wars to some regional wars, including wars between China and Vietnam, China and India, the severe confrontation between China and Taiwan, and some civil wars in such countries as Indonesia, India, Burma, Cambodia, Laos, China, the Philippines, and so on. Samuel Huntington calls the third wave of democratization to spread to Asia, leading to the democratic transition in the Philippines, South Korea, Taiwan, Thailand, Mongolia, and Indonesia. In the meantime, most Asian countries had dramatic economic progress, and Singapore, Hong Kong, South Korea, and Taiwan were considered Asian tigers or Newly Industrial States (NIEs). Further development led to the appearance of China, India, and Indonesia as "emerging countries" in the 2000s.

These are such significant factors, which must have a significant impact on the region or countries' behavior. Realists would expect that the dynamic changes in the distribution of power and conflicts are likely to cause changes in regional countries' internal and external balancing behavior. On the other hand, liberals would expect a more significant international cooperation amongst regional countries due to the spread of democratization and regional institutional frameworks. In either way, given the dynamic changes in Asia in over 60 years, both realists and liberals would be inclined to expect changes in the behavior of Asian countries.

Indonesia and Japan have enjoyed strong ties constantly for the last 60 years. Although Indonesia took the non-alignment stance during the Cold War while Japan firmly positioned itself in the Western camp, it enjoyed strong trade, investment, foreign aid, and financial cooperation. It means any changes in Indonesia's foreign and domestic policies do not create a significant shift toward Indonesia-Japan relations. Indonesia never took the position, neither Capitalism nor Communism (during and after World War II). Japan did not care about the choice. Also, Japan did not present a sudden change in bilateral policy with Indonesia when the Indonesian regime shifted from authoritarian under New Order into a democracy under Reforms Order. So, it has nothing 
to do with the Indonesian Government's choice to maintain its relations with another country. Indonesia's democratization in 1998 did not cause any radical change in terms of bilateral relations. Despite Indonesia's emergence as a middle-income country, the two countries' relations have remained intact. Despite significant changes in Indonesia and the region in the past 60 years, why do Indonesia and Japan continue their cooperation?

Existing literature on Indonesia-Japan relations has not answered this puzzle. The biggest reason for the lack of analysis on this puzzle seems to be that most analysis on the bilateral relations is conducted in terms of area studies. These existing studies have a post-modernist inclination. They give a unique explanation for each case of bilateral cooperation in each period without creating a general argument about the explanatory variables for cooperation between Indonesia and Japan. While the importance of areas studies is not questionable, it is indispensable to conduct a generalized analysis of bilateral relations to understand the significant causes behind the cooperation and predict the two countries' future relations.

In 1958, Indonesia and Japan agreed to sign the Treaty of Peace that became the momentum for both countries to forget the experience and look forward to cooperation (Japan Ministry of Foreign Affairs 2011). Initially, it was agreed that the cooperation would be focused on economic and social issues rather than political ones. Both countries attempted to avoid the trauma of military conflict during world war II was the main reason not to build political ties. Fortunately, Indonesia did not have any political disputes with Japan after Japan's three years of occupation (1942-1945) in Indonesia. Other issues such as territory border, human rights, or property rights were absent from diplomatic discussions between Indonesia and Japan. This situation helped both governments focus solely on economic and social cooperation without disruption due to political tension. Thus, this study examines the IndonesiaJapan bilateral relations on economic and financial aspects. Based on solid research derived from secondary findings and existing discussions on how the two countries have exercised their interests and policies to deal with such bilateral cooperation. This paper attempts to explain that have run through in different cases of the two countries' bilateral economic and financial relations. 
The Dynamics of Indonesia - Japan Economic and Financial Relations: A Review of the 60 Years Collaboration

\section{Development Assistance}

In World War II, Japan attempted to recover its relations with Indonesia through a reciprocation policy. One of the strategies that have been taken to implement this policy is by providing Indonesia with Official Development Assistance (ODA) in the form of loans, grants, and technical assistance. ${ }^{1}$ Previously, Japan's ODA was operated by Overseas Technical Cooperation Agency (OTCA) until JICA took its function in 1974. Since then, Japan International Cooperation Agency (JICA) has become the central agency of Japanese ODA under the Japan Ministry of Foreign Affairs auspices.

In general, the Japan's ODA has at least five objectives as mentioned by Hasegawa in Bahri ( 2004): (1) to support the Japanese efforts for reconstruction and economic growth; (2) to enhance Japan's diplomatic relations; (3) to maintain political, economic and social stabilization of recipient countries for the benefits of Japanese interests; (4) to raise the Japanese income per capita through a commercial flow that is coming back from foreign aid projects; and (5) to boost Japan's influence and leadership both in regional and global fronts. Since the 1990s, the Japan's ODA has diverged into two channels; one aims to support geo-economic orientation, and another to back up humanitarian goals (Trinidad 2007).

Initially, the Japan's ODA for Indonesia was focused on industry, communication and transportation, health, and agriculture (Japan Ministry of Foreign Affairs 2014). Japan started to provide Indonesia with USD14.28 million of grants in 1960. Since then, Japan has continually provided Indonesia with other financial assistance. Following the 1966 Ministerial Conference for the Economic Development of Southeast Asia, Japan agreed to provide Indonesia with USD30 million for economic recovery (Shiraishi 1997). This amount was equivalent to $0.25 \%$ of total Japan's foreign aids between 1967 and 1970, channeled through Inter-Governmental Group for Indonesia (IGGI), a consortium of international donors to assist Indonesia's economic growth recovery. In 1968, Indonesia received the first Japanese ODA loan in commodity loans to deal with the international reserve shortage and deficit on balance of payment (Japan International Cooperation Agency 2018a). According to JICA, until 2015, Indonesia had become the largest recipient of Japanese ODA, occupying $11.3 \%$ of

1 ODA loans refer to any loans dedicated for economic development or for promoting social welfare of recipient country. They usually consist of program and project loans. 
the total Japanese ODA. In the context of Indonesia, the essential objective of Japan's ODA is to build good political and economic relations with Indonesia. Bahri (2010) argues that Japan needs to fix the negative stigma among Indonesians toward Japan due to its annexation during World War II. At the same time, Japan needs natural resources for its production. Therefore, having a good image and good relations will help Japan sustain the supply of natural resources. In addition, Japan's products need a market, in which Indonesia has this potential given its large populations.

Until 2019, Japan had disbursed its ODA to Indonesia in loan, grant, and technical cooperation (see table 1). During 2012-2016, Japan spent much of its loan to support Indonesia's infrastructure development, such as Java-Sumatra Interconnection Transmission Line Project and Mass Rapid Transit Project. For grant, Japan ODA has primarily channeled through Japan non-government organizations' (NGOs) projects. Interestingly, for technical cooperation, Japan disbursed its ODA more on projects related to the environment. Projects such as capacity development for green economic policy, capacity development assistance for low carbon development, and sustainable fishery projects are examples of this cooperation.

Table 1. Japan's ODA to Indonesia

\begin{tabular}{|c|c|c|c|}
\hline \multirow{2}{*}{ Country } & \multicolumn{3}{|c|}{ Japan's ODA (USD million) } \\
\cline { 2 - 4 } & Grant & Technical Assistance & Loans \\
\hline Indonesia & 26.75 & 56.82 & -968.94 \\
\hline
\end{tabular}

Source: Japan's ODA Data for Indonesia (Japan MOFA 2021)

In the early phase of Japan's ODA, the economic relations between Indonesia and Japan were marked by the growing establishment of Japanese companies in Indonesia. This trend was triggered by the high labor costs and the growing protest over environmental degradation faced private sector in Japan (Hall 2002). Therefore, it would have made sense if many Japanese companies relocated their production plants to countries where cheap labors were available, natural resources were plentiful, and environmental issues had not existed yet. One of the options was Indonesia. Unfortunately, Indonesian infrastructure and other supporting elements of the production were feeble due to economic difficulty. 
The Dynamics of Indonesia - Japan Economic and Financial Relations: A Review of the 60 Years Collaboration

Therefore, it might not be coincident if Japan's ODA was initially focused on industry, communication, and transportation. These three areas were vital to support Japanese companies' production line in Indonesia. Without good infrastructures in communication and transportation, Japanese industries in Indonesia would face many challenging situations. Therefore, the focus of the Japanese ODA priority areas was, shifted in 2004. The issues of growth sustainability, democratization, and peace and stability became new areas of the Japan ODA in Indonesia. According to the JICA publication (2018b), Japan provided Indonesia with program loans for financing budget deficits from 2004 to 2014 to facilitate policy reforms. Moreover, the Japanese ODA has supported institutional reforms and capacity development to enhance macroeconomic stabilization.

This change reflects the transformation of the Japan's perspective toward its domestic interests and the development in Indonesia. The Japan's focuses on the industry sector, for instance, while can be viewed as support toward Indonesia's agenda on industrialization, it can also be seen as an attempt to pave the way for Japanese industry to penetrate the Indonesian market. Moreover, Japan's support on transportation infrastructure can be seen as its strategy for providing support for its automotive industry while at the same time providing better connectivity for many Indonesians. Then, the fall of the New Order Regime in Indonesia gave Japan the momentum to change its support for Indonesia, especially to support the democratization process in the most prominent Muslim country in the world. As a process, democratization in Indonesia might affect Japan's economic interests since it might destabilize the status quo.

Moreover, democracy demanded a separation of power that changed the political institution and power configuration. In particular, the executive power under the Soeharto regime was too great compared to legislative and judicative ones and should be limited. Therefore, it became critical for Japan to significantly mitigate or avoid the effects of democratization on its investment in Indonesia. Hence, it would make sense if Japan provided more support on democratization, peace, and stability while securing sustainable growth, concerned with environmental and social aspects. 


\section{Financial Supports}

Strong financial cooperation between Japan and Indonesia has been demonstrated in providing liquidity support assistance and guarantee schemes. At least, there are two crucial cases where Japan provided its financial supports for Indonesia. The first is when Japan contributed USD 5 billion into the International Monetary Package (IMF)'s package to help Indonesia tackle the economic impacts of the Asian Financial Crisis. It is important to understand that Japan's contribution was initially offered on a bilateral basis until the United States of America (USA) pressured Japan to shift its offer into a part of IMF's package (Sujatmiko 1999). It was unclear why the Japanese Government was not able to object to the USA government's intention, making Japan's assistance mixed with the IMF conditional loans that eventually put a burden on the Indonesian economy to some degree.

The second case was when Japan provided USD 1.5 billion for Indonesia as a precautionary measure toward the impact of the Global Financial Crisis (Haswidi 2009). This assistance was channeled in the form of a bond guarantee facility. Having a guarantee from the Japanese Government, the Indonesian yendenominated bond, namely Samurai Bond, was successfully welcomed by the Japanese market. This scheme contributed to support the Indonesian Government's policy to cope with the financial crisis. Since 2015, the GOI had issued Samurai Bonds every year without a guarantee from JBIC and even started to issue Samurai Bonds through a public offering in 2017.

Table 2.

Japan's guarantee for Samurai Bonds

\begin{tabular}{|c|c|c|c|}
\hline Year & $\begin{array}{c}\text { Issuance (JPN } \\
\text { billion) }\end{array}$ & Coupon & $\begin{array}{c}\text { Tenor } \\
\text { (year) }\end{array}$ \\
\hline 2009 & 35 & $2.73 \%$ & 10 \\
\hline 2010 & 60 & $1.60 \%$ & 10 \\
\hline 2012 & 60 & $1.13 \%$ & 10 \\
\hline
\end{tabular}

Source: presentation materials at IMOF-JBIC Policy Dialogue (2019)

Furthermore, according to Bank Indonesia and the Indonesian Ministry of Finance's joint report (2020), Japan is now the second biggest creditor for Indonesia after Singapore. Until February 2020, Japan has been providing Indonesia with USD 28.9 billion 
The Dynamics of Indonesia - Japan Economic and Financial Relations: A Review of the 60 Years Collaboration

loans. This figure was approximately $13.7 \%$ of total Indonesia's foreign debts.

Recently, during the Covid-19 pandemic, Japan provided Indonesia with financial assistance through the ADB program. As part of measures to mitigate the risk of the Covid-19 pandemic, the Indonesian government's sought financing support from bilateral partners. As a result, on August 3, 2020, the Covid-19 Active Response and Expenditure Support Program Loan (CARES) Agreement was signed between the Japanese Government, represented by the Chief Representative of Japan International Cooperation Agency (JICA) Indonesia, and the Indonesia government, represented by the Directorate General of Risk and Financing Management (Japan International Cooperation Agency 2020). The agreement secured Japan's commitment to helping Indonesia, amounting to JPY50 billion, to deal with the impacts of the pandemic.

Bank of Japan (BoJ) and Bank Indonesia had established a bilateral swap arrangement (BSA) regarding short-term liquidity support facilities. The BSA aimed to stabilize and maintain international reserves by establishing a currency swap mechanism. When Indonesia's international reserve was experiencing difficulty (shortage), BoJ will provide US dollars. Later, Bank Indonesia will pay back the same amount it gets from the BoJ in Rupiah. The first Japan-Indonesia BSA was signed in February 2003, amounting to USD 3 billion (Japan Ministry of Finance, 2014). The agreement was renewed in 2005 and increased to USD 6 billion. In 2009, the amount was renewed again and even doubled its size to USD 12 billion (Japan Ministry of Finance, 2014). When the regional self-helped mechanism, namely Chiang Mai Initiative Multilateralization (CMIM) established, Japan kept maintaining its BSA with Indonesia, although it could terminate the arrangement. ${ }^{2}$ This extension of the BSA between Japan and Indonesia reflects another strong relation between the two countries in the financial sector. Since 2013, the amount of the BSA has increased to USD 22.76 billion and will last until 2021 (Purnomo 2018).

In addition to financial assistance, Indonesian and Japanese Ministries of Finance have conducted a policy dialogue since

2 CMIM was intended to replace the BSA with single contractual agreement among ASEAN Plus Three member countries. 
2013. The dialogue, namely Joint Working Group (JWG), is an annual dialogue aimed at discussing technical issues related to cooperation in the financial sector between Indonesia and Japan by involving relevant agencies in both countries. The forum has become a medium for officials from both finance ministries to share their views and experiences on policy issues.

Thevarious financial assistances provided by Japan are not solely for the sake of Indonesia's benefits. For Japan, the financial problems faced by the Indonesian Government led to an opportunity for Japan to pursue broader foreign policy leverage in Indonesia (MacIntyre 2002). In this regard, Tokyo can widen its scope of influence and set the bilateral and regional cooperation agenda by providing financial assistance during financial difficulties. Furthermore, the assistance is also expected to ensure that Indonesia's economy remains stable, which will protect Japan's investments in Indonesia. The financial crisis that hampered the Indonesian economy caused many Japanese investors to suffer heavy losses from the economic collapse. Therefore, having a stable Indonesian economy will assist the protection of Japan's investment in Indonesia.

\section{The Dynamic of Investment}

While Japan has been investing in Indonesia since the early New Order Regime (the 1970s), the new phase of investment relations was promoted by signing the Indonesia-Japan Economic Partnership Agreement (IJEPA) in August 2007 by Prime Minister Shinzo Abe and President Susilo Bambang Yudhoyono. The agreement that started in July 2008 was expected to promote crossborder movements of goods, services, investments, and natural people between Indonesia and Japan (Japan Ministry of Foreign Affairs 2008). This agreement provided more opportunities for Indonesia to access more investments from Japan. In practice, IJEPA encouraged the Indonesian Government to improve several business-related services, including taxation, customs, and regulations.

After several years of IJEPA implementation, the Japanese foreign direct investment showed a positive trend and reached 
The Dynamics of Indonesia - Japan Economic and Financial Relations: A Review of the 60 Years Collaboration

USD3. 6 billion, more than six times compared to the previous year (Japan External Trade Organization 2012). No wonder if, in 2013, Indonesia became the most favorite country for Japanese investment. However, Japan's investment in Indonesia shows declining trend since 2016 (please see figure 1). This situation is worrying since Japan's investment to the rest of the world continually increases during the same period. It means that other countries are becoming more attractive for Japanese investment destinations compared to Indonesia.

Figure 1.

Japan Investment in Indonesia

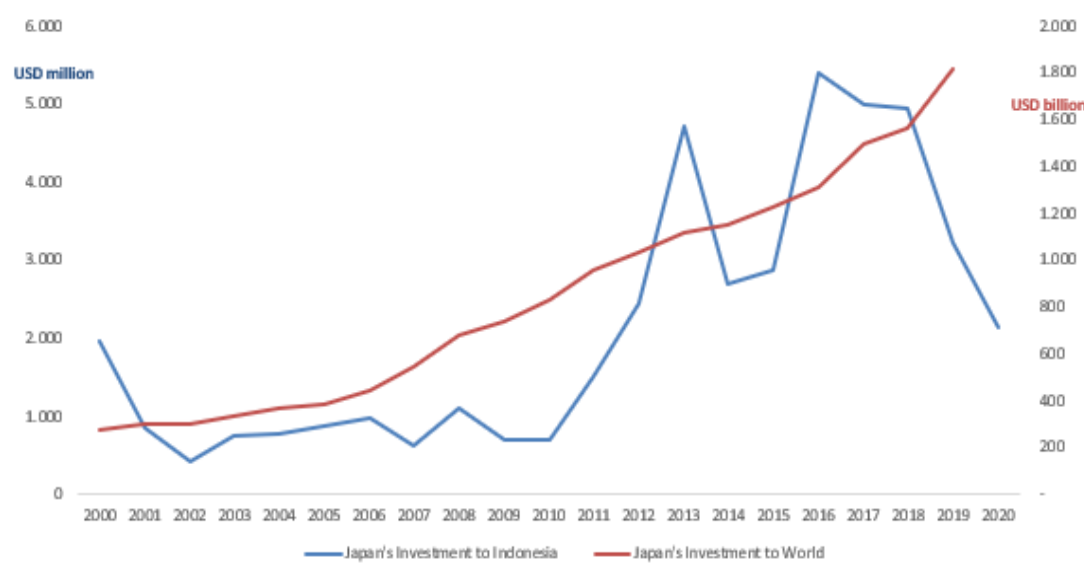

Source: BKPM \& UNCTAD (2021) ${ }^{*} B K P M=$ investment realization; UNCTAD = FDI stock

There are several problems faced by Japanese companies in investing their capital in Indonesia. According to the JBIC survey3, Japanese investors in Indonesia perceived that their satisfaction toward profits was declining. In addition, they face high labor costs, legal uncertainty, low employment retention, and social and security instability. These conditions led to demote Japanese investors' expectations of Indonesia. Therefore, the Indonesian rank for Japanese investment destination dropped to the fifth rank from 2017 to 2019. As a result, Indonesia was left behind

3 Based on the last three JBIC's annual survey on overseas business operations by Japanese Manufacturing Companies 
China, India, Vietnam, and Thailand for the Japanese investment destination.

According to the JETRO survey (2021), Japanese companies expecting operating profits in Indonesia for 2020 to be a surplus accounted for only $37.1 \%$, a significant drop from the 2019 survey (69.1\%) and the 2018 survey (65.5\%). Meanwhile, an increasing number of Japanese affiliated companies in Indonesia expect a loss of up to $75 \%$, a fivefold compared to the 2019 survey (14.9\%). Moreover, the business confidence of Japanese-affiliated companies turned negative in all countries/regions. For Indonesia, Japanese companies anticipating deteriorating situations increased significantly from previous years (2018-2019). As a result, the diffusion index (DI) for Indonesia in 2020 was marked at -65.9 points. ${ }^{4}$ This number is above the DI for the ASEAN bloc, which is -46.7 points. For comparison, the DI for Indonesia in 2018 was 27.7 points (ASEAN 23.6 points), while in 2019 was 14.2 points (ASEAN 8.8 points).

Furthermore, the intention of Japanese affiliated companies in Indonesia to expand business in 1-2 years ahead dropped to 37.7 points. In comparison, the 2019 survey was 50.7points, and the 2018 points were 49.2 points. India was the only country that exceeding the majority with 50.9\% of "Expansion". Within ASEAN, $46.8 \%$ of companies plan to expand in Vietnam, while Thailand is below Indonesia with $31.5 \%$. Among primary reasons, sales increase in local markets and high growth potentials are two main reasons why Japanese affiliated companies in Indonesia expand with $85.5 \%$ and $41 \%$, respectively.

Regarding challenges faced by Japanese affiliated-companies in Indonesia, the increased wage remains the biggest management issue. For the three consecutive years times, Increased wages have been the main issue raised by the companies, although the percentage has declined from $78.2 \%$ (2018), 84\% (2019), and $77.4 \%$ (2020). In Indonesia, the wage increase rate decreased every year after peaking out at $24.7 \%$ in 2013 . The rate was $6.3 \%$ in 2020 and is expected to be $4.9 \%$ in 2021 (forecast), showing a continued decrease. Other important issues that become operational concerns

4 The diffusion index (DI) is the proportion of businesses reporting increased operating profits minus those reporting decreased operating profits 
The Dynamics of Indonesia - Japan Economic and Financial Relations: A Review of the 60 Years Collaboration

are (i) a decrease in order volume from business partners (62.9\%), (ii) sluggishness in significant sales markets (consumption downturn) (53.5\%), and (iii) difficulty in local procurement of raw materials and parts (52.6\%). The proportion of companies that faced the latter problem declined compared to the 2018 survey (60.1\%) and 2019 survey (59.4\%), signaling the improvement in getting local materials and parts.

In response to the investment challenges, the Government of Indonesia has made several efforts. In 2020, the government issued the Omnibus Law on Job Creation as a major reform to unlock potential investments and create more jobs. It was designed from a long-term perspective to increase competitiveness with an immediate impact on national economic recovery. Part of the innovative approach introduced by the Omnibus Law is the establishment of the Indonesian SWF (Indonesia Investment Authority/INA) as a new platform of investing in Indonesia that would give more certainty while taking the opportunity to invest through equity financing. ${ }^{5}$ It aspires to become a trusted investment partner for international and domestic investors (s) for Indonesia's long-term and sustainable economic development. At this point, JBIC has presented its initial commitment to participate in the INA, amounting to JPY 4 billion, which reflects Japan's positive view toward the Indonesian investment opportunity (Indonesia Ministry of Foreign Affairs 2020).

\section{Trade Performance}

In 2020, the total trade between the two countries was valued at USD24.3 billion, making Japan the 3rd most significant trading partner. Meanwhile, Indonesia is the 11th largest trading for Japan with $2 \%$ export and $3 \%$ import contribution. Indonesia's exports to Japan are mineral fuels (Natural Gas and Bituminous Coal), electrical parts (cable), and rubber. Meanwhile, Indonesia's imports from Japan are dominated by machinery, vehicles and parts, and iron and steel as Indonesia's main exports to Japan. The domination of natural gas and coal reflects unchanged Indonesian

5 Article 165, The law No.11/2020 on Job Creation 
behavior of exporting natural resources without additional values.

Indonesia has enormous export potentials other than oil and gas commodities. According to the International Trade Centre (2021), the enormous export potentials from Indonesia to Japan are nickel mattes, shrimps \& prawns, frozen plywood, veneered panel, \& similar laminated wood (see figure 2). The shrimps \& prawns have export potentials up to USD536.4 million, while the actual exports are only USD293.7 million currently. Therefore, there is an untapped potential of about USD242.6 million. Meanwhile, fish fillets have an export potential of around USD157.2 million. With its actual exports of only USD35.2 million, this product has an untapped potential of about USD121.9 million.

\section{Figure 2.}

Indonesia Export Potentials to Japan

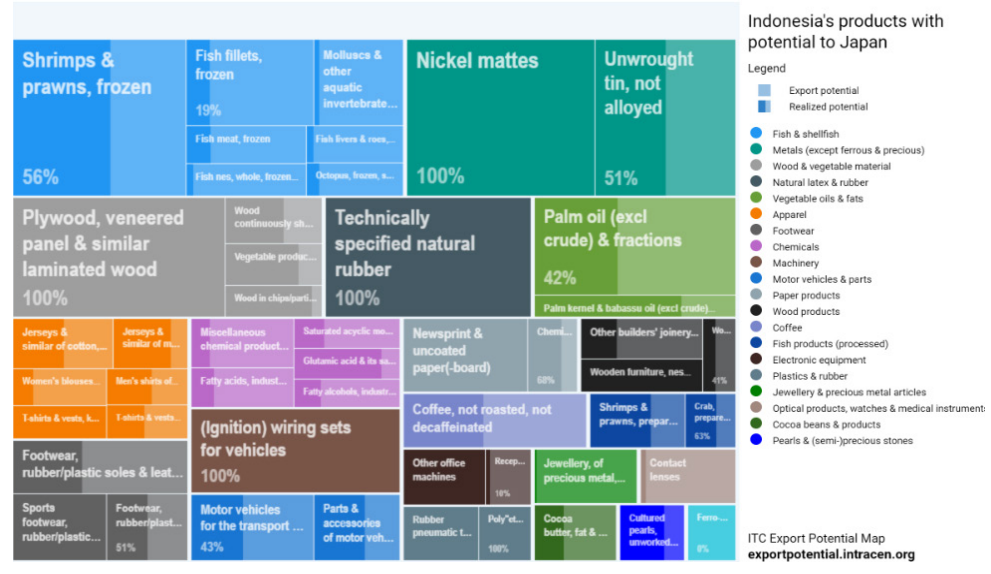

Source: ITC Tools, Trademap (2021)

From 2018 to 2020, Indonesian-Japan total trade showed a negative trend (see table 3). In this regard, Indonesia has consistently recorded a trade surplus with Japan since 2001, despite the continuous decline of trade value. However, until 2019, this achievement was somewhat vague since the surplus for the Indonesia side was mainly supported by oil and gas. Therefore, if the contribution of oil and gas is excluded, Indonesia would gain a trade deficit. Interestingly, in 2020, Indonesia recorded a surplus for non-oil and gas trade with Japan. 
The Dynamics of Indonesia - Japan Economic and Financial Relations: A Review of the 60 Years Collaboration

Figure 3.

Indonesia-Japan Trade Performance (2016-2020)

Indonesia-Japan Trade

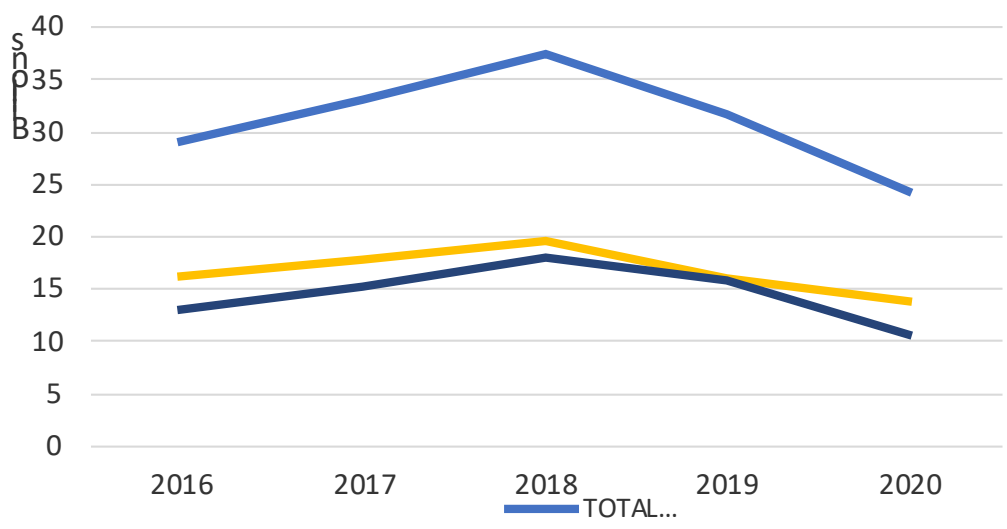

Source: Indonesian Ministry of Trade (2021)

The growing dominance of Chinese products in Indonesia may become one factor contributing to the declining trend of IndonesiaJapan trade performance. Compared to total trade with Japan, total trade between Indonesia and China is almost always double. For instance, for the 2019 fiscal year, the total trade between Indonesia and China was USD 72.89 billion, while with Japan, it was around USD 31.66 billion (Indonesia Ministry of Trade 2021).

Another factor that may lead to the declining trend is the recent Japanese economic situation. For instance, Japan experienced a recession in the first quarter of 2020. In the fourth quarter of 2019, the country experienced negative economic growth due to the increase in sales tax which suppressed consumption. In addition, the Japanese manufacturing sector has also decreased significantly. Apart from the lockdown, this was also caused by a declining world demand for Japanese manufactured goods by $0.2 \%$, which contributed $16 \%$ to the economy. The weakening of the manufacturing sector in Japan directly impacts the decline in coal and natural gas exports from Indonesia to Japan. Indonesia's coal exports to Japan have decreased by $-\mathbf{2 2 . 9 \%}$, while Indonesia's gas exports to Japan have decreased by $-65.2 \%$ from USD1.28 billion to USD448 million during the pandemic. 
The JETRO's survey (2021) found that the decrease in order volume from business partners is the biggest problem for Japanese affiliated companies in Indonesia. This finding parallels the situation faced by Japanese companies in bonded zones (Kawasan Berikat) and the companies that granted import concession for export purposes (Kemudahan Impor Tujuan Ekspor/KITE). According to DG Customs data (2021), exports from Japanese companies in bonded zones and Japanese companies with KITE in 2020 experienced a significant contraction (-17.38\%) with a value of USD6.5 billion. This value contributed to $10.57 \%$ of exports from national bonded zones and all companies with KITE. In comparison, the companies contributed $12.38 \%$ in 2019. Among other companies, those Japanese companies classified in electronics and parts, automotive, and plastic industries experienced a significant decline in sales for 2020.

Looking at the dynamic, the recent bilateral trade between Indonesia and Japan shows a relatively sound performance despite the challenging impacts of the Covid-19 pandemic. The lower demand in Japan triggered the declining trend due to the pandemic that affecting production capacity. Nevertheless, the situation is not the end of the dynamics itself. It is expected that the trade performance will gradually rebound along with the vaccination-also, other recovery programs both in Japan and Indonesia.

\section{Conclusion}

Japan still provides ODA to Indonesia, although the value and focus of the assistance have changed. Since 2016, Indonesia was no longer becoming Japan's top priority of ODA, and the areas of assistance also shifted into more on strengthening institutions and capacity development, including sustainable growth. However, the transformation of Japan's ODA areas of interest in Indonesia does not exclude its economic objection from the list.

Indonesia and Japan have been working closely to build tight financial cooperation in the area of liquidity support. As a result, several initiatives, including bilateral swap arrangement, financial assistance for Covid-19 handling, and policy dialogue between 
The Dynamics of Indonesia - Japan Economic and Financial Relations: A Review of the 60 Years Collaboration

relevant financial authorities have been established. These initiatives add necessary financial cooperation that was previously established during Asian Financial Crisis and Global Financial Crisis.

Furthermore, Japanese investment in Indonesia has shown a declining trend since 2016. Several issues have become constraints for Japanese investments, ranging from regulatory impediments to managerial issues. The Indonesian government has taken several reforms to promote a better investment climate to boost investors' confidence in investing in Indonesia. However, the result of these efforts toward Japanese investment may only be seen in several years ahead. In terms of trade performance, Indonesia and Japan are likely facing a similar situation during the Covid-19 pandemic that pressured the two countries on both supply and demand sides. Therefore, along with the declining demand from Japan's domestic demand, Indonesia's exports also experienced a declining trend. However, this trend is likely to be reversed, in line with the implementation of various economic recovery programs in Japan and Indonesia.

\section{References}

\section{Book and Chapter in Book}

MacIntyre, Andrew. 2002. "Japan, Indonesia, and Policy Leadership in the Pacific: Economic Crisis and Foreign Policy Opportunities". In T. Inoguchi (Ed.), Japan's Asia Policy: Revival and Response. New York: Palgrave Macmillan, pp 193-210.

Shiraishi, Takashi, and Peter J. Katzenstein. 1997. Network power: Japan and Asia Cornell University Press: Ithaca.

\section{Journal and Online Journal}

Bahri, M Mossadeq. 2010. "International Aid for Development? An Overview Japanese ODA to Indonesia”, Hubs-Asia, 10 (1).

Hall, Derek. 2002. "Environmental Change, Protest, and Havens of Environmental Degradation: Evidence from Asia”, Global 
Environmental Politics, 2 (2): 20-28.

Sujatmiko. 1999. "Japan's role in overcoming the Indonesian economic crisis”, Asia-Pacific Review, 6 (1): 109-31.

Trinidad, Dennis D. 2007. “Japan's ODA at the crossroads: disbursement patterns of Japan's development assistance to southeast Asia”, Asian Perspective, 95-125.

\section{Online Articles}

Haswidi, Andi, and Aditya Suharmoko. 2009. "RI, Japan ink fresh 1.5t yen swap deal", The Jakarta Post [online]. in http://www. thejakartapost.com/news/2009/07/07/ri-japan-ink-fresh-15t-yenswap-deal.html [accessed July 22, 2021].

Indonesia Ministry of Foreign Affairs. 2020. "Coordinating Minister Luhut Pandjaitan: Japan to Invest IDR57T to Support Indonesia's Sovereign Wealth Fund"' [online]. in https:// kemlu.go.id/portal/en/read/1954/berita/coordinating-ministerluhut-pandjaitan-japan-to-invest-idr57t-to-support-indonesiassovereign-wealth-fund [accessed July 23, 2021]

International Trade Centre. 2021. "Export Potential Map: From Indonesia to Japan.” [online]. in https://exportpotential. intracen.org/en/products/tree-map?fromMarker=i\&exporte $\mathrm{r}=360 \&$ toMarker $=\mathrm{j} \&$ market $=392 \&$ whatMarker $=\mathrm{k}$.

Japan External Trade Organization. 2012. "Japan's Outward and Inward Foreign Direct Investment”, [online]. in https://www. jetro.go.jp/en/reports/statistics/. [accessed April 25, 2021].

Japan International Cooperation Agency, Japan. 2020. "Signing of Japanese ODA Loan Agreement with the Republic of Indonesia: Contributing to COVID-19 crisis response in the Republic of Indonesia through providing budget support", [online]. in https://www.jica.go.jp/english/news/press/2020/20200803 10 en.html. [accessed April 27, 2021]

Japan Ministry of Finance, Japan. 2014. “Joint Press Release on the Signing of the agreement on an increase in the maximum amount of the Bilateral Swap Arrangements between Japan and Indonesia under the Chiang Mai Initiative", [online]. in http://www.mof.go.jp/english/international policy/ 
The Dynamics of Indonesia - Japan Economic and Financial Relations: A Review of the 60 Years Collaboration

financial cooperation in asia/regional financial cooperation/ pcmie/og0406press release.pdf. [accessed May 13, 2021]

Japan Ministry of Finance. 2011. “Japan's Bilateral Swap Arrangements (BSAs) under the Chiang Mai Initiative (CMI)”, [online]. in http://www.mof.go.jp/english/international_policy/ financial cooperation in asia/regional financial cooperation/ pcmie/index.htm. [accessed December 19, 2011]

Japan Ministry of Foreign Affairs. 2008. “Joint Press Statement on the Occasion of the entry into force of the Agreement between Japan and the Republic of Indonesia for an Economic Partnership", [online]. in http://www.mofa.go.jp/region/asiapaci/indonesia/jointo807.html. [accessed May 13, 2021]

Japan Ministry of Foreign Affairs. 2011. "Japan-Indonesia Relations", [online]. in http://www.mofa.go.jp/region/asia-paci/ indonesia/index.html. [accessed July 22, 2021].

Japan Ministry of Foreign Affairs. 2014. "Japan's ODA: Rolling Plan for the Republic of Indonesia”, [online]. in http:// www.mofa.go.jp/policy/oda/rolling plans/pdfs/indonesia.pdf. [accessed May 13, 2021].

Japan Ministry of Foreign Affairs. 2021. "Japan's ODA Data for Indonesia”, [online]. in https://www.mofa.go.jp/ files/oo0142543.pdf [accessed April 5, 2021]

Purnomo, Herdaru. 2018. "BI dan BOJ Perbarui Kerja Sama Swap US\$ 22,76 M (BI and BOJ renewed swap cooperation US\$ 22.76 billion)", CNBC Indonesia, [online]. in https://www. cnbcindonesia.com/market/20181015101903-17-37365/bi-danboj-perbarui-kerja-sama-swap-us--2276-m. [accessed April 27, 2021]

\section{Others}

Bank Indonesia \& Indonesian Ministry of Finance. 2020. "External Debt Statistics of Indonesia". Jakarta: Bank Indonesia \& Indonesian Ministry of Finance.

Indonesia DG Custom. 2021. "Pertumbuhan Transaksi Kawasan Berikat (KB) dan Kemudahan Impor Tujuan Ekspor (KITE) Investasi Jepang." Indonesia DG Custom. 
Indonesia Ministry of Trade. 2021. "Neraca Perdagangan Dengan Mitra Dagang (Trade Balance with Bilateral Partner)." Jakarta: Indonesia Ministry of Trade.

Japan External Trade Organization. 2021. "2020 Survey of Japanese Companies in Asia and Oceania.” Tokyo: JETRO.

Japan International Cooperation Agency. 2018a. "Indonesia's Development and Japan's Cooperation: Building the Future Based on Trust.” JICA.

Japan International Cooperation Agency. 2018b. "Review of Indonesia's Development and Japan's Cooperation: Its Past, Present and Future in the Republic of Indonesia." Tokyo: JICA. 
The Dynamics of Indonesia - Japan Economic and Financial Relations:

A Review of the 60 Years Collaboration 